\title{
Legal Protection of Minority Shareholders (Acquisition Company in Indonesia and Malaysia)
}

\author{
Sigit Somadiyono \\ Law Faculty, Batanghari Jambi University \\ J1. Slamet Riyadi, Broni, Jambi- Indonesia Tel/Fax: 0741-65351 \\ Correspondence email: sigitsomadiyono82@gmail.com
}

\begin{abstract}
The objective of research was to analyze the comparative legal provisions concerning the implementation regulation of the Legal Protection of Minority Shareholders in Context Acquisition Company in Indonesia and Malaysia. The journal is compiled with normative juridical research method with the approach of legislation, the conceptual approach and the approach of comparative law. Based on the survey results was revealed that basically the concept and criteria of legal protection of minority stockholders in the context of the acquisition of the same company. While suitability setting the position of trainee Shares Minority In Context Acquisition of Companies in Indonesia in accordance with the regulations but very difficult to implement because of the overlap with the rules above while in the Royal Malaysian implementation is very smooth due to the form of the rules in the form of legislation even though there are still gaps that need to be fixed in legislation there especially in the aspect that is still loose and often manipulated by the majority shareholders.
\end{abstract}

\section{Keywords: Comparative Law, Legal Protection, Minority Shareholders}

Abstrak. Tujuan penelitian adalah untuk menganalisis ketentuan hukum komparatif mengenai peraturan pelaksanaan Perlindungan Hukum Pemegang Saham Minoritas dalam Akuisisi Perusahaan di Indonesia dan Malaysia. Jurnal ini disusun dengan metode penelitian yuridis normatif dengan pendekatan legislasi, pendekatan konseptual dan pendekatan hukum perbandingan. Berdasarkan hasil survei terungkap bahwa pada dasarnya konsep dan kriteria perlindungan hukum terhadap pemegang saham minoritas dalam konteks akuisisi perusahaan yang sama. Sementara kesesuaian pengaturan posisi trainee Saham Minoritas Dalam Pengadaan Akuisisi Perusahaan di Indonesia sesuai dengan peraturan tetapi sangat sulit untuk dilaksanakan karena tumpang tindih dengan aturan di atas sedangkan dalam pelaksanaan Royal Malaysia sangat lancar karena bentuk aturan dalam bentuk undang-undang meskipun masih ada celah yang perlu diperbaiki dalam undang-undang di sana terutama dalam aspek yang masih longgar dan sering dimanipulasi oleh pemegang saham mayoritas.

Kata Kunci: Hukum Komparatif, Perlindungan Hukum, Pemegang Saham Minoritas

\section{Introduction}

Significant changes in the business environment such as globalization deregulation and technological advances have created a very tight competition. One strategy to become a large company and can compete among the existing competition by means of restructuring the company, one of them through acquisitions. The term "acquisition" is often called "take over" is performed by the takeover of a company by buying a majority share of companies that took over control over the capital of other companies. ${ }^{1}$ This acquisition aims to expand the business of a company, especially in the field of business. This is reinforced by the statement Hitt et al., ${ }^{2}$ stated that the acquisition is one form of structuring of the earliest companies that are widely used with a view to develop business and improve operations. But at the time decided to make acquisitions, in some companies found their minority shareholders who disagree with the actions of a limited liability company will be faced with the risk harmed by the power of the majority shareholder of losing votes in the General Meeting of Shareholders (AGM).

Therefore, in Indonesia Article 126 paragraph (1) Limited Liability Company Act of 2007 stipulates that a legal act of acquisition shall take into account the interests of the rights of minority shareholders. ${ }^{3}$ Limited Liability Company Act emphasizes the protection of the rights of minority shareholders for Law Company Limited has the assumption that the actual implementation of the acquisition only for the interests of the majority shareholder, then of course the majority shareholder would not have agreed at the AGM to carry out the acquisition, thus the acquisition can not be executed, or the majority shareholders may terminate the acquisition by replacing directors who are considered uncooperative with the majority shareholder. Such authorizations are only owned by the majority shareholder and not owned by the minority shareholders ${ }^{4}$

\footnotetext{
${ }^{1}$ Haryani, Iswi dkk, Merger, Konsolidasi, Akuisisi, dan Pemisahan Perusahaan: Cara Cerdas Mengembangkan dan Memajukan Perusahaan, Cetakan Pertama, Visi Media: Jakarta.2011

${ }^{2}$ Hitt et al., Merger, Akuisisi dan Divestasi. (edisi ke-1). Yogyakarta: Ekonisia, 2003

${ }^{3}$ Haryani, Iswi dkk, op.cit.

${ }^{4}$ Munir Fuady, Hukum tentang Akuisisi, Take Over dan LBO, (Bandung; Penerbit PT. Citra Aditya Bakti, 2001
} 
However, the Company is comprised of several parties who have rights in the company, namely the form of shares. So that in running a company, the parties concerned should have a tangle of balance, namely in the form of majority rule and minority protection. This means that the ruling remains the majority shareholder but where possible also must consider the interests of minority shareholders. ${ }^{5}$ In other words, the interests of minority shareholders in a company often neglected or even harmed. This is because there is a strong perception that the most meritorious enlarge the financial coffers of the company, is the majority shareholder. Mastery of the physical volume of the stock or capital infusion to the company, provide strong support or later evidence against this perception. That perception is reinforced by the principles espoused one share one vote in the limited liability company. Thus, in each GMS minority shareholders will probably never win a decision taken through voting. At the operational level, the composition of the board of directors or commissioners constantly occupied or controlled by the majority shareholders. However, the limited liability company law provides certain rights or derivative rights to minority shareholders who own at least $10 \%$ of the shares, to protect the rights and interests in the company, especially against the arbitrariness of the majority shareholder. In fact, in certain cases, a minority shareholder can act on behalf of companies to sue directors for his misdeeds had acted hurt the company. In addition, there are a number of other rights that can be used by minority shareholders to protect and promote the rights and interests, so as not harmed its interests in the company

For that, an important resource for protecting minority investors is through legal mechanisms. This is because the legal system would ensure the legitimate rights and security of shareholders' investments. Also according to the study La Porta ${ }^{67}$ the quality of enforcement by law enforcement authorities and the courts is an important element for the successfully of efficient gocernance company. Additionally, shareholder activism is an alternative to maintain the rights of minority shareholders. Shareholder Activism refers to efforts to preserve the rights of minority investors through the power of equity holdings and generate actions that cause profits to investors. ${ }^{8}$

Further, these protecting minority investors through legal mechanisms not only implemented in Indonesia but also in other countries which is categorized as "The countries where investors have the most protection" such Singapore and Malaysia. According to World Bank ${ }^{9}$ Malaysia is considered an emerging economy, beside that Indonesia and Malaysia have the same law system which is very regular and systematic and have customs and races of Malay. Further researcher interest to compare Indonesia and Malaysia because related to minority shareholders, each country is equally not allowed to prosecute lawsuits. Minority shareholders can not nominate an independent director and the candidate may be elected. Also viewed from the Chairman of the CEO and directors in Indonesia and Malaysia are the same ie 1 person who is not separated.

Based on the above problems, the authors are interested in discussing further how Interns Legal Protection against Minority shares holder in Context Acquisitions in Indonesia by comparing against Malaysia.

\section{Problem Statement}

With the background described above, it is known that the problem is formulated as follows: What is the regulation on the implementation of Legal Protection of Minority Shareholders in the Acquisition Content of Companies in Indonesia and Malaysia?

\section{Objective of the Research}

The objective of research was to analyze the comparative legal provisions concerning the implementation regulation of the Legal Protection of Minority Shareholders in Context Acquisition Company in Indonesia and Malaysia

\section{Method}

To support the writing of this article, the method used is the method of normative legal research. Normative legal research is a legal research that puts the law as a norm system building. The system of norms is about the principles, norms, rules of legislation, court decisions, agreements and doctrines. ${ }^{10}$ Legal research is usually done with library research methods which are usually referred to as normative law, which emphasizes the approach of legislation

\footnotetext{
5 Ibid.

${ }^{6}$ La Porta, Rafael; Lopez-de-Silanes, Florencio; Shleifer, Andrei; dan Vishny, Robert. "Law dan Finance.” Journal of Political Economy. No. 106. 1998. hlm.1113-1155

7 La Porta, Rafael; Lopez-de-Silanes, Florencio; Shleifer, Andrei; dan Vishny, Robert. “Agency Problems and Dividend Policies Around the World." Journal of Finance. Vol. 55. 2000. hlm. 1-33

${ }^{8}$ Rashid, Ameer dan Rashidah Abdul Rahman. (2009). The impact of minority shareholder watchdog group activism on the performance of targeted firm in Malaysia, Asian Academy of Management Journal of Accounting and Finance, 5(1), 67--92

${ }^{9} \mathrm{https}$ //www.investopedia.com/financial-edge/0812/countries-with-the-best-and-worst-investor-protection.aspx

${ }^{10}$ Mukti Fajar ND dan Yulianto Achmad, Dualisme Penelitian Hukum Normatif \& Empiris, Yogyakarta : Pustaka Pelajar, 2015, hlm. 34
} 
of the Republic of Indonesia and Malysia by reviewing the laws of the Republic of Indonesia and Malysia relating to the protection of law against the minority shareholders by Law of the Republic of Indonesia Number 40 of 2007 on Limited Liability Company and Companies Act 1965, the Securities Commission Act 1993 (Act 498), the Malaysian Code on Acquisitions and mergers in 1998 and 2004 (Malaysian Code on Take-Overs and mergers).

This paper use a qualitative approach as the analysis method in which the author will inventory all laws of the Republic of Indonesia and Malysia then analyzed the legal systematic by examining the basic understanding of the system of law relating to the protection of minority shareholders and then the facts of the existing legal as a form of safeguard minority shareholders then draw the conclusions.

\section{Result and Discussion}

Legislation in Indonesia does not provide a definition of minority shareholders explicitly, but in a Limited Liability Companies Act No. 40 of 2007 gives the notion of shareholder implicitly as contained in Article 79 Paragraph (2) b, Article 97 (6), Article 113 Paragraph (6), Article 138 Paragraph (3) a, Article 144 Paragraph (1), namely that 1 (one) or more shareholders who together to represent 1/10 (one tenth) the number of shares or more of the total shares with voting rights can be deduced that the minority shareholders are parties that have a stake of no more than $20 \%$ (twenty percent) of the voting rights of all shares issued by a company with voting rights. So that, the minority shareholders is only acquire a controlling stake in a small number of less magnitude than the number of shares which is dominated by the other shareholders in a company

The position of minority shareholders in a company is often overlooked even harmed. This may happen because of majority's perception that shareholders have a significant role in the progress of a company, especially in terms of capital income. The assumption that the majority shareholder of the most instrumental in growing domination of the company's financial coffers evidenced by the percentage volume of capital inflows to company.

This is further strengthened by the existence of one share one vote principle contained in Article 84 of Law No. 40 of 2007 on Limited Liability Companies. So that when the AGM is held, minority shareholders have never won when decisions are made by voting. This is all due to both the board of commissioners and directors of the company are majority shareholders who certainly have a large volume of shares in these firms.

Given the interests of minority shareholders are often the victims, causing losses to the minority shareholders, to the Act No. 40 of 2007 on Limited Liability Companies doing some breakthroughs, which had actually been carried out by several of the Company Law in developed countries. Among these breakthroughs is the protection of minority shareholders. Law No. 40 of 2007 on Limited Liability Companies provides protection through its articles can be used as the basis of the rights of minority shareholders in the company.

In addition, one of the rights owned by minority shareholders is the right to a dissenting opinion, which is the right to dissent, including not approving decisions and specific actions undertaken by the directors. Such actions must be the act a substantial shareholder and the company as a whole, such as mergers, acquisitions and others.

Meanwhile, according to Fitzgerald, as quoted Satjipto Raharjo ${ }^{11}$ the beginning of the emergence of the theory of legal protection is derived from the theory of natural law or the flow of natural law. This stream was pioneered by Plato, Aristotle (a student of Plato), and Zeno (the founder of the Stoic). According to the flow of natural law states that law that comes from God is universal and timeless, and between law and morality should not be separated. These adherents view the legal and moral reflection and rules internally and externally of human life which is realized through legal and moral.

In the opinion of Hadjon Phillipus ${ }^{12}$ stated that the legal protection for the people as government actions that are preventive and repressive. Protection preventive law aims to prevent disputes, which directing the actions of the government to be cautious in making decision discretion, and the protection of repressive aims to resolve disputes, including in handling the judiciary institutions.

Legal protection is an act or an attempt to protect the public from arbitrary actions by the authorities is not in accordance with the rule of law, to bring order and peace so as to enable people to enjoy dignity as human beings. ${ }^{13}$ While Harjono ${ }^{14}$ stated that legal protection as by means of legal protection or protection conferred by law, aimed at the protection of particular interests, namely by making interest be protected from such a legal right. It could say that legal protection is protection provided on the basis of law and legislation. The legal protection could mean protection

\footnotetext{
${ }^{11}$ Satjipto Raharjo, Ilmu Hukum, PT. Citra Aditya Bakti, Bandung, 2000, hlm.53

12 Phillipus M. Hadjon, Perlindungan Hukum Bagi Rakyat Indonesia, PT. Bina Ilmu, Surabaya: 1987. hlm.29

${ }^{13}$ Setiono, Rule of Law (Supremasi Hukum). Surakarta. Magister Ilmu Hukum Program versitas Sebelas Maret. 2004.
}

hlm. 3

${ }^{14}$ Harjono, 2008, Konstitusi sebagai Rumah Bangsa, Sekretariat Jenderal dan Kepaniteraan Mahkamah Konstitusi, hlm. 
provided to law so as not to be interpreted differently and not to harm by law enforcement officials and it can also mean the protection provided by the law against something ${ }^{15}$

In addition, according to Law No. 40 of 2007, the legal protections that can be provided include: Protection of Minority Shareholders through Appraisal Rights, Protection of Minority Shareholders via Silent Majority. In other words, to protect the interests of minority shareholders on the implementation of the acquisition were unilateral, the Law on Limited Liability Companies No. 40 of 2007 provides protection by Article 62 paragraph (1) which entitles shareholders who did not agree to ask to buy back shares reasonable price (appraisal rights). In addition, the protection of minority shareholders can be found through the silent majority principle in this case the majority shareholder are not allowed to be involved in decisions on the acquisition

Further, In Indonesia, the provision contained in the acquisition of some of the legislation. For example, in Act No. 40 of 2007 Article 1 number 11 explains that "The acquisition is a legal act carried out by legal entities or individuals to take stock of the Company which resulted expert shift of control of the company". In contrast to Regulation No. 27 Year 1998 regarding the Merger, Consolidation, and Acquisition Company Limited clause 1 number 3 explains that "The acquisition is a legal act carried out by legal entities or natural persons to acquire either the whole or a large part of the company's shares which may result in the shift of control against the company." Similarities between the Government Regulation No. 27 of 1998 by Law No. 40 of 2007, that the acquisition of foreclosed are shares owned by the company, excluding asset acquisition or other acquisition as a business.

This condition proved theory stated by M.A.Weinberg as a foreign legal expert explained that the acquisition is an act that committed by individuals, groups of individuals, or companies, as well as cover the acquisition of wealth and the acquisition of shares. Unlike the American legal expert Scharf, explained that the acquisition can only be conducted by a single company. Also according to Scharf, the acquisitions is all action of corporate transactions involving the sale and purchase all or as assets, shares or other securities forms, between two companies, each of which acts as a seller and a buyer. It concluded that in the United States, understanding this acquisition is an action which also includes mergers, consolidation and other corporate actions. Agus Daryanto cited by Siahaan ${ }^{16}$ explained that the purpose of the acquisition is to improve the management system of the company acquired. Weak management of the Company will be difficult to develop even though they have more funds. So that the company is not able to compete with other companies, especially companies similar and is likely to cause destruction. So as a way to save her is that it can be combined with the group how conglomeration who are experienced in the field of management by selling most of its shares to the conglomerate groups.

As for Malaysia, there are two main methods in carrying out the company entities control over something that is, whether the acquisition of a retail or acquisition of the assets and liabilities of the company overall. ${ }^{17}$ Selection of any one technique is dependent on factors purpose behind the acquisition, the acquiring company owned resources, the target company's financial condition and other factors such as tax considerations. Implications of the acquisition would cause the control to move to the acquiring company and certain reply-paid to the holders of the shareholders of the target company for the acquisition of their equity. Instead there is a specific law to monitor the implementation of activities related to the acquisition of companies in Malaysia namely Companies Act 1965, the Securities Commission Act 1993 (Act 498), the Malaysian Code on Acquisitions and mergers in 1998 and 2004. (Malaysian Code on TakeOvers and Mergers). Beside that, minority shareholders' rights are protected via the following methods: Supermajority approval, Remedy for oppression in court: Section 181 of the Companies Act provides judicial relief if: (i) the company's affairs are conducted or the directors' powers are exercised in a manner oppressive to one or more of the members or holders of debentures or in disregard of the interests of the member(s), shareholder(s) or holder(s) of debentures or (ii) some act of the company has been done or is threatened or some resolution has been passed or is proposed which unfairly discriminates against or is otherwise prejudicial to one or more members or holders of debentures, Contractual agreement: Shareholders may contract by way of a shareholders' agreement as to the rights and benefits of minorities.

Beside that, in Malaysia minority shareholders' rights are protected via the following methods:

1. Supermajority approval.

2. Remedy for oppression in court: Section 181 of the Companies Act provides judicial relief if:

a. the company's affairs are conducted or the directors' powers are exercised in a manner oppressive to one or more of the members or holders of debentures or in disregard of the interests of the member(s), shareholder(s) or holder(s) of debentures

${ }^{15}$ Sudikno Mertokusumo, Penemuan Hukum, Citra Aditya Bakti, Bandung, 2009. hlm. 38

${ }^{16}$ Magdalena Marnala Siahaan, Tinjauan Yuridis Atas Akuisisi Perusahaan Setelah Berlakunya Undang-Undang Nomor 40 Tahun 2007 Terntang Perseroan Terbatas, Tesis Ilmu Hukum, Universitas Sumatera Utara, 2011, hlm. 140

17 Moyer, R.C., McGuigan, J.R. dan Kretlow. Contemporary financial management. Edisi ke--8. Australia: South-Western College Publishing Thomson Leraning. 2001 
b. Some act of the company has been done or is threatened or some resolution has been passed or is proposed which unfairly discriminates against or is otherwise prejudicial to one or more members or holders of debentures.

3. Contractual agreement: Shareholders may contract by way of a shareholders' agreement as to the rights and benefits of minorities.

That legal protection conducted by Companies Act 1965 as follow:

1. Class rights protection

A company is justified in making the rights of different classes, such as the right to obtain a major dividend for a particular shareholder. However, if major class rights, such as the right to participate in the GMS or the right to vote are annulled by majority classes, minority shareholders may petition the Court in this regard.

2. Protection upon amendment of memorandum

In the Companies Act 1965, a change of memorandum shall be notified before 21 days. Along with this also included notis that contains anything that will be changed in the memorandum.

If the minority shareholder does not agree with the content of the notes it also means objected to the points to be amended in the memorandum, then he has the right to file the matter to the Court. It is the court that is authorized to decide whether the objections are accepted or rejected. If it is accepted then the contents of the memorandum can not be changed in accordance with the existing plan on the notes.

3. The existence of an unjust prejudice

An unfair prejudice is a treatment or action that has the potential to create injustice, such as the non-reporting of the company's financial statements, adidaya discrimination and others.

Should such matter occur, then minority shareholders may take it to the Court as regulated in s.16 of the Company's Deed.

4. Inspection by the authorized Minister

The examination by the minister shall be made if there is a request from the parties as regulated in s.197 of the deed of the Company. Minister c.q examiner yag diutusnya can conduct inspection to a company on request. If in the examination found negative results, such as prejudice, then the minister can make a petition to the Court. In this context, everything depends on the minister.

5. The existence of the right to argue based on s. 65 and the right of recus- tion based on s.144

The minority shareholder may denial upon the basis of s 65 (4) for any amendment to the memorandum which he deems harmful to him. The party yag can argue is required to have a share of at least $1 / 10$ of the total shares of the company. The denial is submitted to the Court.

Another right is the right of recusing is the right to refute the results of the deliberation or AGM. The requirement before the denial is sent to the competent authorities in Malaysia, the denial must be signed by the rectifier. Anyone who can propose this right is also required to have at least $1 / 10$ of the total shares.

The results found that the protection of minority shareholders on the issue of acquisition of the company is to be a warning-emptor implemented through regulations such as the Company Law, the Deed The Securities and Mergers and Acquisitions Code (Malaysian Code on Take-Overs and Mergers). The situation information is not symmetrical between investors and internal management has enabled the majority shareholder and management find space of legal gaps to promote or implement their interests.

Basically, the legal tools in Indonesia have been trying to protect minority shareholders. Some regulations such as the Limited Liability Company Law (UU PT) in 2007, Decision of the Chairman of Bapepam-LK Number VIII.G7 / BL / 2012, PSAK 7 (R2009) and Bank Indonesia Regulation Number 14/14 / PBI / 2012 actually require transparency and require disclosure of parties treated equally in fair transactions. Meanwhile in Malaysia the regulation about that is more scecific as stated in Companies Act 1965, the Securities Commission Act 1993 (Act 498), the Malaysian Code on Acquisitions and mergers in 1998 and 2004. (Malaysian Code on Take-Overs and Mergers).

Taking into account the findings of the protection situation of the holder a minority stake in some cases take over in Malaysia. The first implication is identified is a form of imperfection the legal mechanisms, especially in the context of the situation complex transactions. For example, the term "majority consent" contained in Article 132 must be evaluated Practical effects upward interests of minority shareholders action to make mechanism "agreement" as to be more protective, requiring the approval of a majority fixing certain percent higher than a simple majority.

Beside that, by considering the various regulations and the institutions involved to control the activity of M \& A in Malaysia, alignment should be realized between any law, code regulatory and enforcement agencies so as to ensure investment protection to minority shareholders. As expressed by La Porta ${ }^{18}$, the minority shareholders are not

${ }^{18}$ La Porta, Rafael; Lopez-de-Silanes, Florencio; Shleifer, Andrei; dan Vishny, Robert. "Agency Problems and Dividend Policies Around the World.” Journal of Finance. Vol. 55. 2000. hlm. 1-33 
have many options in defending rights than its majority shareholders and because of these factors legislative should be more concerned to protect the interests of minority shareholders. Continuous should be taken to close gaps that still exist in the legal provisions for the purpose of preserving the interests of the minority. Based on research by Orin (2008), which saw the provision of Article 406 of the Sarbanes Oxley 2002 as the livelihood integrating ethical dimension into deed through Specifying a top management ethics code, so in the long term there must be efforts to create a context doctrinally protection warning vendor that is by increasing the urge to shareholders majority to act on behalf of the interests of all investors, including minority shareholders. In the early stages it can imposed in the form of law who specializes code of conduct the highest management of an entity.

In addition, this study also reinforces the results of research conducted by Claessens et al., ${ }^{1920}$ that examines the expropriation of minority shareholders in public companies in nine Asian countries by examining the effects of the separation of cash flow rights and the right of control over corporate value and examine the ownership structure of companies in nine countries in East Asia. The result is concentrated ownership in Indonesia, where the ownership is achieved in various ways, namely pyramid structure, cross ownership, and management of ownership. Indonesia shows the largest pyramid ownership structure of $66.9 \%$ of the sample and the second largest in management and ownership management, after Malaysia, which is $84.6 \%$ of the sample of Indonesian companies.

In other words, this indicates that the structure of minority shareholdings in Indonesia compared to Malaysia has the highest concentration of ownership while also proved the results of research conducted by La Porta et al., ${ }^{2122}$ who argue that the lack of legal and institutional protection (law and enforcement) are closely related to concentrated ownership. Beside that, the various protections afforded, either under common law conventions in Indonesia, as well as in the Companies Act 1965in Malaysia, require the activeness of minority shareholders. Unlike the case with Malaysia, Indonesia is a country that applies its laws based on civil law. One of the characteristics of a civil law enforcement state is the weak legal protection of shareholders. ${ }^{23}$ The rights of these minority shareholders are often under-paid by the majority shareholders concerned with decision-making within the company

\section{Conclusion}

Interns Minority Shares in Context Acquisition of Companies in Indonesia in accordance with the regulations but very difficult to implement because of the overlap with the above rules, while at the Royal Malaysian exist in the form of a warning emptor. The use of legal provisions have been provide basic infrastructure to safeguard the interests of investors minority. However, there are still gaps that need to be corrected in existing legislation, especially in the aspect that is still loose and often manipulated by the majority shareholders. Other than that, quality legal ethics to be followed by commitment and integrity in the parties involved in the transaction involved, particularly the majority of investors are more influential in choosing something actions and decisions.

\section{References: \\ Books}

Hariyani, et.al, Merger, Konsilidasi, Akuisisi, dan Pemisahan Perusahaaan, Jakarta Selatan: Visimedia, 2011

Harjono, Konstitusi sebagai Rumah Bangsa, Sekretariat Jenderal dan Kepaniteraan Mahkamah Konstitusi, 2008, hlm. 357.

Hitt, M.A., Ireland, R.D. dan Hoskisson, R.E. Strategic management: competitivenss and globalization. Australia: Thomson South--Western, 2003

Moyer, R.C., McGuigan, J.R. dan Kretlow. 2001. Contemporary financial management. Edisi ke--8. Australia: South-Western College Publishing Thomson Leraning. 2001

Munir Fuady, Hukum tentang Akuisisi, Take Over dan LBO, (Bandung; Penerbit PT. Citra Aditya Bakti, 2001

Mukti Fajar ND dan Yulianto Achmad, Dualisme Penelitian Hukum Normatif \& Empiris, Yogyakarta : Pustaka Pelajar, 2015, hlm. 34

Pemerintah Indonesia, Kamus Besar Bahasa Indonesia, Balai Pustaka, 1995. hlm. 762.

Phillipus M. Hadjon, Perlindungan Hukum Bagi Rakyat Indonesia, PT. Bina Ilmu, Surabaya: 1987. hlm.29.

${ }^{19}$ Claessens, Stijin; Djankov, Simeon; Fan, Joseph; dan Lang, Larry H.P. "Expropriation of Minority Shareholders:

Evidence from East Asia." Policy Research Paper 2088. World Bank, Washington, DC. 1999.

${ }^{20}$ Claessens, Stijin; Djankov, Simeon; dan Lang, Larry H.P. "The Separation of Ownership and Control in East Asian Corporations." Journal of Financial Economics. Vol. 58. 2000. hlm. 81-112

${ }^{21}$ La Porta, Rafael; Lopez-de-Silanes, Florencio; Shleifer, Andrei; dan Vishny, Robert. "Law dan Finance." Journal of Political Economy. No. 106. 1998. hlm.1113-1155

${ }^{22}$ La Porta, Rafael; Lopez-de-Silanes, Florencio; Shleifer, Andrei; dan Vishny, Robert. "Agency Problems and Dividend Policies Around the World.” Journal of Finance. Vol. 55. 2000. hlm. 1-33

${ }^{23}$ Hung, M. Accounting standards and value relevance of financial statements: An international analysis. Journal of Accounting and Economics, 30(3), 2000. hlm. 401-420 
Satjipto Raharjo, Ilmu Hukum, PT. Citra Aditya Bakti, Bandung, 2000, hlm.53

Sudikno Mertokusumo, Penemuan Hukum, Citra Aditya Bakti, Bandung, 2009. hlm. 38

\section{Researches}

Anwar, Miranda, Pencatatan Saham Lewat Belakang (Backdoor Listing) Dengan Cara Melakukan Akuisis (Studi Kasus : Akuisisi PT.Fatrapolindonusa Industri TBK, Oleh Titian International CORP.SDN.BHD), Skripsi Ilmu Hukum, Universitas Indonesia, 2008, hlm. 1526 Sere Magdalena Marnala Siahaan, Tinjauan Yuridis Atas Akuisisi Perusahaan Setelah Berlakunya Undang-Undang Nomor 40 Tahun 2007 Terntang Perseroan Terbatas, Tesis Ilmu Hukum, Universitas Sumatera Utara, 2011, hlm. 140

Setiono, Rule of Law (Supremasi Hukum). Surakarta. Magister Ilmu Hukum Program versitas Sebelas Maret. 2004. hlm. 3

Siahaan, Magdalena Marnala, Tinjauan Yuridis Atas Akuisisi Perusahaan Setelah Berlakunya Undang-Undang Nomor 40 Tahun 2007 Terntang Perseroan Terbatas, Tesis Ilmu Hukum, Universitas Sumatera Utara, 2011, hlm. 140

\section{Journals}

Ameer, Rashid dan Rahman, Rashidah Abdul. The impact of minority shareholder watchdog group activism on the performance of targeted firm in Malaysia, Asian Academy of Management Journal of Accounting and Finance, 5(1), 2009, hlm.67--92

Claessens, Stijin; Djankov, Simeon; Fan, Joseph; dan Lang, Larry H.P. "Expropriation of Minority Shareholders: Evidence from East Asia." Policy Research Paper 2088. World Bank, Washington, DC. 1999.

Claessens, Stijin; Djankov, Simeon; dan Lang, Larry H.P. "The Separation of Ownership and Control in East Asian Corporations.” Journal of Financial Economics. Vol. 58. 2000. hlm. 81-112

Hung, M. Accounting standards and value relevance of financial statements: An international analysis. Journal of Accounting and Economics, 30(3), 2000. hlm. 401-420

La Porta, R., Lopez--de--Silanes, F. dan Shleifer, A.. Law and finance, Journal of Political Economy, 106(6), 1998, hlm.1113--1155.

La Porta, R., Lopez--de--Silanes, F., Shleifer, A. dan Vishny, R. Investor protection and corporate governance. Journal of Financial Economics, 58, 2000, hlm.3--27.

Orin, R.M. Ethical guidance and constraint under the Sarbanes - Oxley Act of 2002. Journal of Accounting, Auditing and Finance, 23(1), 2008, hlm.141--171.

Warf, B. Mergers and acquisition in the telecommunication industry. Growth and Change, 34(3), 2003, hlm.321--344

\section{Regulations}

Companies Act 1965 of Malaysia about Public Company Limited by Shares

Law of the Republic of Indonesia Number 40 of 2007 on Limited Liability Company

The Securities Commission Act 1993 (Act 498), Securities Commission Maysia

The Malaysian Code on Take-Overs and mergers, 1998 